\title{
Involvement of Survey Professional Organizations in International Activities
}

\author{
Rabin K. Sharma \\ President \\ Nepal Remote Sensing and Photogrammetric Society \\ e-mail : sharma19434@alumni.itc.nl
}

\section{Introduction}

Some of the major works of the organizations from survey profession are to create and disseminate spatial and non-spatial data, to produce proper human resources and also to recommend policy on geoinformatics for implementing development activities of the country. So these organizations have greater role and responsibilities in the process of building the nation. Some of the responsibilities of the organization are to educate and enhance the knowledge of the officials of the organization, to keep abreast in the recent technologies available in the world and to build capacity of the organization for customer's satisfaction and to disseminate the data and information related to mapping effectively. In order to fulfill these responsibilities, the professionals of the organization must have proper education and should be competent enough among their colleagues within the organization and counterparts from abroad. The means to develop their competency could be combination of the net surfing, reading proceedings of the conferences, studying higher level education, attending refresher courses in a particular topic, participating conference/ workshop, etc. In the present context of globalization in technological development, an organization without having its staffs reasonably competent, it will be hard to follow the technological development trend. Therefore the organization should create environment to allow the staffs for participation in international activities and interact, discuss and share the knowledge with the experts, researchers, and scientists from other parts of the world. There are so many international activities occurring throughout the year in different parts of the globe. In most cases, it is open to all. However, all the staffs in the organization may not have ability to prove herself/himself as a competent staff, so the organization should have mechanism to choose the correct event, in right time and proper staff for attending the event.

\section{Survey Professional Organizations of Nepal}

Although the modern technology of surveying and mapping has entered in Nepal, organizations involved in survey profession have not been able to discard the classical methods and so they are dealing parallel both with classical and modern approaches of surveying and mapping. The reasons could be unavailability of required number of new generation of professionals and the financial support needed to establish the advanced technology.

In the modern technology of surveying and mapping, every steps of the procedure such as data acquisition, data processing, data analysis and visualizations, and data dissemination has to handle with the computer based systems. Furthermore, the development in the domain of surveying and mapping is so rapid that the professionals involved in this discipline need to update their knowledge and skills more frequently. Hence there is a greater role of teaching institutes to upgrade and update the knowledge of the human resources working in the organizations and to produce fresh candidates for the recent technology.

On the other hand, there are few professional organizations of survey profession which are established to advocate, promote and assure the related organizations to apply technology for the process of national development and also to recommend the means to provide efficient and effective service delivery to the users. So noting the existence of number of organizations related to survey profession in Nepal, this article shall limited to Survey Department, Land Management Training Centre and Nepal Remote Sensing and Photogrammetric Society of Nepal in order to represent a government organization, a teaching institute and a professional organization respectively. Furthermore, these organizations are trying to give more and more exposure in the international forums. 


\section{Activities of International Organizations}

There are so many international organizations established around the globe with specific objectives related with surveying and mapping, remote sensing, earth observation and space technology. Some of the common objectives are to share the knowledge and information on research activities and to pursue and promote to adopt newly developed technology in application of diverse field such as surveying and mapping, land resource management, weather forecasting, disaster prevention, and etcetera. The means of communicating information to the related organizations around the world are the activities defined by the corresponding international organization such as training programme, conference, workshop, meeting, summit, project implementation, dissemination of information through e-news, etc.

\section{Involvement in the Activities}

Survey Department, Land Management Training Centre and Nepal Remote Sensing and Photogrammetric Society are moving ahead to achieve the goals defined in their respective objectives. They have one objective is in common which is clearly visible from their corresponding activities that they are trying to give their exposure into international arena and to involve in the activities of related international organizations as far as possible although there are limited financial resources and constraints to invest the resources.

\subsection{Survey Department}

Survey Department was established in 1957 AD mainly for cadastral mapping to assist in the collection of land revenue. Due to advancement in the technology of surveying and mapping field and also considering the responsibility to deliver services efficiently to variety of disciplines for their current demand of the different categories of maps and data, the scope has been widened to greater perspective to apply several advance technologies. In the process of acquiring, processing and dissemination of spatial and non-spatial data, Survey Department had so many projects jointly implemented with concerned foreign agencies under different grant cooperation programme of respective Governments. The details can be obtained either from the brochure of the department or by net surfing the webpage of the department (www.dos.gov.np). Furthermore, on November 2009 AD, Survey Department signed on a Memorandum of Understanding with National Space Institute, Technical University of Denmark for taking up Airborne Gravity measurement programme to achieve a modern geoid model of Nepal to contribute to Geodetic Network Infrastructure Programme of Nepal.

Under the policy to expose the department into the international forum, Survey Department joined number of International Organizations as a member. Involvement of the department in the activities of those organizations can be summarized as follows:

- Survey Department joined Permanent Committee on GIS Infrastructure for Asia and the Pacific (PCGIAP) in $1995 \mathrm{AD}$ and then participated in the preparation of Cadastral Template of Nepal; the template was designed by PCGIAP in 2003 AD. The information of the template of Nepal can be viewed in the official webpage of PCGIAP (www.pcgiap.org). It needs to be regularly updated.

- Survey Department, Ministry of Foreign Affairs and Nepal Academy of Science and Technology (NAST) jointly conducted First SAARC Technical Meeting on Cartography on March 1995 to discuss in the common problems specifically on environment degradation and unplanned land and other natural resources. In the meeting, a SAARC Networking Arrangements on Cartography (SNAC) was formed to pursue further for common benefits of the SAARC member countries and since then the Director General of Survey Department is the Chair of the Committee.

- The department became ordinary member of Asian Association on Remote Sensing (AARS) during $19^{\text {th }}$ Asian Conference on Remote Sensing (ACRS) held at Hong Kong in 1999 AD. Since then the department had been regularly participating in ACRS. The department also successfully conducted the $23^{\text {rd }}$ ACRS with approximately 450 participants (more than 200 participants from abroad) in Kathmandu. Now it is again the right time to conduct next ACRS so the department should take initiations to propose at AARS.

- The department joined International Steering Committee for Global Mapping (ISCGM) in 2000 $\mathrm{AD}$ as a Category $\mathrm{B}$ member of the Committee. In this category, the member country itself has to prepare global spatial data of the country at the scale of $1: 1 \mathrm{M}$ with spatial data resolution of $1 \mathrm{~km} \times 1 \mathrm{~km}$. But at that time, the department does not have capacity to prepare the data mainly due to lack of skilled human resources and the competent technology. However, Survey Department managed to prepare the data working jointly with Geographical Survey Institute 
(GSI) of Japan. ISCGM released the global data of six countries including Nepal as a version 1.0 on November 2000 AD. The data can be viewed from the official webpage of ISCGM (www.iscgm.org). After the establishment of National Topographic Database (NTDB) of Nepal, the department is committed to provide updated Global data of Nepal as soon as possible and the department is working hard to prepare the data based on the specifications released by ISCGM.

- The department became Affiliate Member of International Federation of Surveyors (FIG) in 2002 AD. The membership was awarded to Survey Department by FIG during XXII ${ }^{\text {th }}$ FIG Congress held at Washington D.C. on April 2002 AD. There are 10 Commissions working under FIG in which Survey Department appointed National Delegates except in Commission 4: Hydrology, as the scope of work of this discipline has no direct relation with that of Survey Department. The further details of the Commissions of FIG can be viewed from the webpage of FIG (www.fig.net). On February 17, 2009, Survey Department organized a lecture program in honour of Dr. Stig Enemark, President of FIG where he delivered a lecture on "Land Administration Systems: managing rights, restrictions and responsibilities in Land"

- The department received the membership of Asia Pacific Regional Space Agency Forum (APRSAF) at the $10^{\text {th }}$ Session of the APRSAF which was held at Chiang Mai, Thailand in 2003 AD. Since then the department continuously attending the sessions of APRSAF.

- The department received membership of Group on Earth Observations (GEO) during GEO-4 meeting which was held at Tokyo, Japan on April 2004 AD. Since then the department participated the number of Ministerial Level Summits and other GEO preparatory meetings. GEO already launched 10 years implementation plan of Global Earth Observation Systems of System (GEOSS), accordingly the department will have to take necessary steps in implementation.

- After establishment of National Geographic Information Infrastructure Programme in Survey Department, the department applied the membership for Global Spatial Data Infrastructure Association (GSDIA) and received the membership in 2004 AD. The department occasionally attended the events organized by the Association.

- Survey Department joined Sentinel Asia Joint Project
Team (SA JPT) from the very beginning of the project in $2006 \mathrm{AD}$. The project regularly organized the general meeting in different parts of the Asian countries where official from the department took part in the events. The project so far conducted four Sentinel Asia Operational System Trainings in different city of the Asian countries and the officials of the department participated in all of these training programmes. During Koshi flood in 2008 AD, the department prepared flood map of affected areas for the evaluation of damage caused by the flood and to prepare a plan of action for relief operation using satellite data received through Sentinel Asia Project.

Besides the activities mentioned above, the department has been involved in so many other events of other international organizations. Few of which will be discussed as follows:

- United Nations Education and Social Commission for Asia and the Pacific (UNESCAP) whose Head Quarters is based at Bangkok, Thailand organize United Nations Regional Cartographic Conference for Asia and the Pacific (UNRCCAP) and Ordnance Survey of Great Britain organize Cambridge Conference in regular interval of time period. These two organizations never miss to invite Survey Department to participate in their corresponding events and whenever situation permits the department showed up actively in the events.

- In the early period of Survey Department, the department regularly received scholarships from Japan International Cooperation Agency (JICA) to study Training Course on Surveying and Mapping at Geographical Survey Institute (GSI), Japan. So few of the staffs of the department got opportunity to study the course in Japan. A Follow-up Study Team from JICA visited Survey Department to conduct a "Seminar on Surveying and Mapping" for ex-participants of the Training Course. The seminar was successfully conducted in Kathmandu, Nepal on October 29, 1997.

- The relation between ITC, The Netherlands and Survey Department was established from 1978 AD and four of the officials of the department got opportunity to study at ITC under Dutch Government scholarship programme in the same year. The author was one of the first officials to join ITC from Survey Department which was also quoted in the official webpage of ITC (www.itc.nl). The relationship was renewed at a special function organized by the department to welcome Prof. Dr. Martien Molenaar, the then Rector 
of ITC during his visit to Nepal for giving Keynote speech in the $23^{\text {rd }}$ ACRS organized in Kathmandu on November 2002 AD. Few years back, ITC has started ITC scholarship programme and some of the officials also received chances to study under this programme. One very worthwhile fact to mention here is, when Mr. Sjaack Beerens, Director, Foreign Affairs of ITC visited Survey Department in 2007 AD, just before the Golden Jubilee celebration of Survey Department, he announced to award ITC scholarship to one of the staffs of the department in the name of Golden Jubilee Celebration of Survey Department at a special function organized by the department to welcome him and received the scholarship for one of the staffs of the department. The lucky staff of the department to receive this award was Mr. Krishna Prasad Sapkota, the then Survey Officer of Survey Department.

- Since 2004 AD, Survey Department established relationship with Asian Institute of Technology (AIT), Bangkok Thailand through Mini-project which was designed jointly by Japan Aerospace Exploration Agency (JAXA) and Asian Institute of Technology (AIT). The objective of the mini-project is to implement space development programmes for promoting space technology utilization. This is one of the ways of JAXA to cooperate developing nations to encourage using space technology for different purposes such as evaluation of natural disaster, hazard mapping, etc.

\subsection{Land Management Training Centre (LMTC)}

Land Management Training Centre (LMTC), originally its name was Survey Training Centre, was established in 1969 AD as one of the Branches of Survey Department to impart training course for Amins (Basic Surveyors) only. Its scope of work has been gradually increase to impart junior and surveyor course to meet the demands of the skilled technicians from several organizations. In 1999 AD, Ministry of Land Reform and Management remodeled its organizational structure and in this process, the Centre has been upgraded to department level and placed directly under its own umbrella by adding more responsibilities for imparting training programmes for Land Managers. Since then the name of the Centre has been changed to Land Management Training Centre. More information of LMTC can be viewed in the webpage of LMTC (www.lmtc.gov.np).

In the early period of LMTC, it has received human resources cooperation for the post of Principal and Instructors through Indian Cooperation Mission (ICM) under Colombo Plan Programme of Government of India.
The officials involved in this programme were from Survey of India. The project was terminated in 1980 AD. Again, some Volunteers for a limited period under the project of Japanese Overseas Cooperation Volunteer (JOCV) of Japanese International Cooperation Agency (JICA) of Government of Japan also received for supporting training progarmmes of LMTC.

Land Management Training Centre (LMTC) decided to expose the organization in international forums. So, it is gradually increasing its participation in some of the international activities. The results of its involvement are as follows:

- LMTC became the Academic Member of International Federation of Surveyors (FIG) in 2006 AD. When the President of FIG, Dr. Stig Enemark visited LMTC on February 2009, LMTC organized a lecture programme to welcome the President and the President delivered a lecture on "Promoting the Interaction between Education, Research and Professional Practices" on February 16, 2009.

- LMTC received the membership of Sentinel Asia Joint Project Team (SA JPT) in 2009 AD. Prior to become the member, some of the officials of LMTC had already attended the Sentinel Asia Operational System Training Programme. After having the membership of SA JPT, the Centre attended first time in the $3^{\text {rd }}$ Sentinel Asia JPT meeting held at Indonesia in 2009 $\mathrm{AD}$ and also the fourth Sentinel Asia Operational Training programme held at Sri Lanka in 2010 AD.

- Noting the usefulness after participation of the $23^{\text {rd }}$ ACRS which was held at Kathmandu in 2002 AD, LMTC proposed to the Government of Nepal through its annual program for attending the ACRS of AARS mainly for capacity building of its staffs from the fiscal year 2005-2006 (2063-64 BS). After getting approval from the government, the officials of LMTC attended the $26^{\text {th }}$ ACRS which was held at Hanoi, Vietnam in $2005 \mathrm{AD}$ and then continued for participation in the ACRS events regularly.

- LMTC and Kathmandu University (KU), Dhulikhel jointly commenced Bachelor Degree in Geomatics Engineering from 2007 AD. Then a "Fact Finding Mission" having a team of experts from ITC, The Netherlands visited Nepal on April 2008 AD for exploring the activities to develop mutual cooperation between LMTC and KU and a report containing 12 activities was submitted. Based on the report and getting approval from the ITC and the government of Nepal, a "Workshop on Curriculum Development for Bachelor Degree, Geomatics Engineering" was successfully conducted on October 2008 AD. 
Furthermore, Dutch Government and ITC, the Netherlands sanctioned scholarships for studying different courses in the institute for the staffs of LMTC as well as KU. Under this scheme, five officials from LMTC and two from KU had completed the course and three more staffs of LMTC are studying at the institute.

\subsection{Nepal Remote Sensing and Photogrammetric ociety (NRSPS)}

Nepal Remote Sensing and Photogrammetric Society (NRSPS) was established in 1991 AD mainly to promote related organizations for applying photo grammetric and remote sensing technology in various fields of national development. More information on NRSPS is available in the webpage of NRSPS (www. nrsps.org.np). Involvement of NRSPS in the activities of International organizations is not much but most of its members are involved directly or indirectly in the international activities through their respective working office. However, NRSPS is trying to give as much exposure as possible in international forums and the achievement so far made can be summarized as follows:

- Since 1994 AD, NRSPS is an Ordinary Member of International Society for Photogrammetry and Remote Sensing (ISPRS) and whenever possible some of the members of NRSPS participated in the events of ISPRS such as Congress, Workshops and Council Meetings, etc.

- Asia Pacific Regional Space Agency Forum (APRSAF) awarded the membership to NRSPS in 2007 AD. The President of NRSPS participated first time in the event of APRSAF which was the $16^{\text {th }}$ Session of APRSAF held from January 26-29, 2009 at Bangkok, Thailand.

\section{Benefits}

Involvement of an organization in international events is a positive response with respect to the globalization principle of working together in a common platform. So there will be benefits to the organizations which could be analyzed as follows:

- Participants could gain experiences and acquire knowledge on the theme of the event by sharing information with the professionals, scientists and experts participated from different parts of the globe

- Presentation of status and research activities of the organization will definitely give not only exposure of the organization in international forum but also could attracts number of international organizations for developing relationship between the two organization by implementing feasible project which could benefits mutually.

- If an international event be organized in the country it will benefits in number of aspects such as help and support for technological development in the organization, get opportunity to participate by a large number of local technicians in an international event at a time, able to establish identity of the country in technological field, help in promotion of tourism, etc.

Since participation of the events by the survey professionals creates not only the opportunity to share the experiences and gain knowledge on the topic but also helps to establish its competency. So this could be considered as one of the means to educate the officials of the organizations and to keep abreast in the recent technologies available in the world. Hence, the organizations should encourage its officials to participate in international events as many as possible.

\section{Improvement}

Participation in the international events alone by the staffs may not help to give proper exposure of the organization in international forum but the participant should display a competent professionalism in the field. In order to achieve this, some improvements within the organization and changing attitude of the staffs are inevitable. The corresponding organization should support the individual for its capacity building and at the same time the individual should develop some characteristics to obey the ethics and code of conduct of the professionalism, some of which could be listed as follows:

- Give opportunity to participate in the international events

- Encourage to prepare quality technical and research papers to present in the events

- Create environment to share the experiences and knowledge with the colleagues before and after participation of an event

- Maintain diary of the international events and share the information with the colleagues

- Habituate to study the current technological development to update the information

- Develop presentation skill for delivering the lecture

- Build capacity to discuss and handle the issues that could raise during discussion period 
- Show sportsmanship to discuss the issues with the subordinates, colleagues and the managers

- Display positive attitude while arguing in the topic

\section{Conclusions}

It is clear that the organizations of survey profession mentioned in the articles are giving more and more exposure in the international community by participation of the events organized by the international organizations. The benefits for the organization and for the country could be increased further by organizing regularly the events in the country which is lacking at present and concerned organizations should take initiations in this line of thoughts. In order to give proper exposure of the country or organization in particular, the professionals of the organization should posses a quality of professionalism which could be developed by following some criteria identified above. Hence participation in international events not only gives exposure of the organization but also provides opportunity to enhance the knowledge of its officials.

\section{References}

1. LeafletofNepalRemote Sensing andPhotogrammetric Society (NRSPS); 2009

2. Photo Profile; Land Management Training Centre; 2008

3. Rabin K. Sharma, Profession and Professional Organizations in Nepalese Context; paper presented in XXI IS ISPRS Congress 2008, Beijing China; July 3-11, 2008

4. Rabin K. Sharma: Survey Department in the Forum of International Activities: A Brief Overview; Nepalese Journal on Geoinformatics, Number 3, 2004

5. Survey Department at a Glance; 2009

6. Umesh Kumar and Rabin K. Sharma, Need of Professionalism in Geomatics Profession for the Development of Sustainable System; Nepalese Journal on Geoinformatics, Number 8, 2009. 